\title{
The Influence of Headmaster Leadership and Discipline on Teachers Performance at Lempuing Jaya Ogan Komering Ilir Subdistrict
}

\author{
Kastubi $^{1 *}$, Happy Fitria ${ }^{2}$, Achmad Wahidy $^{2}$ \\ ${ }^{1}$ SD Negeri Kecamatan Lempuing Jaya Regency Ogan Komering Ilir 1 \\ ${ }^{2}$ Universitas PGRI Palembang \\ *Corresponding author. E-mail: abikastubi@gmail.com
}

\begin{abstract}
Principal leadership was a teacher who has the ability to lead, guide, mobilize and manage all resources in a school including teacher work discipline. Hence, they can work effectively in order to plan and implement school programs to increase achievement and achieve common goals. The purpose of this study was to determine the effect of principal leadership and teacher work discipline either partially or simultaneously on teacher performance. This research method used a correlational quantitative type with a total of 265 teachers for the study using proportional random sampling in order to obtain a sample of 73 respondents. Data collection techniques used documentation and questionnaires. The data analysis technique used the $\mathrm{T}$ test and $\mathrm{F}$ test. The results of this study can be concluded that there was an influence of the principal's leadership and teacher work discipline either partially or simultaneously on the performance of elementary school teachers at Lempuing Jaya District Ogan Komering Ilir
\end{abstract}

Keywords: Principal Leadership, Teacher Performance, Headmaster Leadership

\section{INTRODUCTION}

Education is the basic capital to create superior human resources. The main world of education is schools. The school is one of the alternative educational services institutions. School as an institution certainly has a vision, mission, objectives and functions. To carry out the mission, realize the vision, achieve goals, and carry out its functions the school requires professionals, organizational work procedures and resources that support both financial and non-financial. Schools as a system have components that are related to each other and contribute to the achievement of goals. The components are students, curriculum, teaching materials, learning and outcomes process, environment, facilities, teacher facilities, and principal as leaders.

Leadership is said to be a process of directing and influencing activities that have to do with the work of group members. There are three important implications in this regard, namely, firstly, the leadership involves others, both leadership involves the distribution of power between the leader and the group members in a balanced manner because the group is not without power [1], the third is the ability to use different forms of power to influence the behavior of subordinates through various means.

The headmaster must act as an effective manager and leader. As a good manager, the headmaster must be able to manage all the potentials of the school to function optimally in supporting the achievement of the school's objectives. This can be done if the headmaster is able to perform the school management functions properly which include: (1) planning; (2) organizing; (3) briefing; and (4) supervision and cooperation with teachers. The headmaster's leadership had a significant impact on the teacher's performance. Similarly, Tabrani [2] stated that the headmaster's leadership has an influence on the teacher's performance so that the teacher's performance does not release from the influence of the headmaster's leadership. Because the better the headmaster's leadership, the more improved 
the teacher's performance in carrying out his duties as an educator. This was also confirmed stated that the headmaster's leadership is very instrumental in improving the spirit of teacher work in carrying out their duties so that they can create harmonious and pleasant working conditions [3]. Thus, teachers will be more passionate in fostering students both academic and non-academic. In addition, according to Mulyasa stated that the headmaster's leadership provides work motivation for improving teacher work productivity and student learning outcomes. [4]

According to Supriadi in his book (editor) History of Engineering and Vocational Education in Indones There are seven indicators of a principal's success, namely the Principal as The Manager, the Principal as the Leader, the principal as the Entrepreneur, the principal as the Creator of the Working Climate, the principal as the Educator, the principal as the Administrator, and the principal as the Supervisor.

The headmaster who is able to perform the above functions well can be said that the headmaster has good leadership ability. Thus, it is clear that the headmaster as a leader in order to succeed must perform at least seven of the above functions in addition to having other criteria such as his educational background and experience. The headmaster in addition to being able to lead, managing the school is also required to be able to create a conducive atmosphere in the work environment so as to motivate teachers in the work and can prevent the onset of disintegration or division in the organization.

Teachers are one of the professional educators and scientists with the main task of transforming, developing and disseminating science, technology and the arts through education, research and community service is the definition of a teacher in accordance with UURINo14Year 2005aboutGurudanDosen Article 1 paragraph 2. Teachers become one of the elements that affect the success of the school. Therefore, teachers must have certain characteristics such as good character and morals, values, practices, open, dynamic, assertive, and constantly evaluating their work and themselves [5] As professionals, the duties and responsibilities of teachers include teaching and educating. Teachers who implement engagement and appreciation strategies are considered to be more effective teachers [6] Physical involvement and level of conformity have a significant effect on learning satisfaction and learning effectiveness. In addition, learning satisfaction has a positive influence on the effectiveness of learning [7] one part of the education process and must have good performance [8]

Teacher performance as the level of success of teachers in the implementation of educational tasks as well as their responsibilities and authorities based on performance standards that have been set during a certain period in order to achieve educational goals [9]. One of the school's chief duties is to monitor teacher performance assessments. In the Teacher Performance Assessment there are assessment criteria, among others: educational qualifications, curriculum development, learning planning, learning implementation, learning assessment, teacher professional development and additional tasks / other activities. Discipline is a supporter of the implementation of tasks in accordance with the rules with ideal circumstances to support work optimization [10]. Discipline is indispensable to both individuals and organizations. For example, if a teacher is late entering the classroom to teach, then the class can become inconsistual and can interfere with the activity of learning to pursue other classes. According to 10 explained that good work discipline will improve employee performance in this case teachers so as to accelerate the achievement of organizational goals, while low discipline will decrease employee performance so that it becomes a barrier and slow down the achievement of organizational goals.

Ability, skill, and motivation will contribute positively to the quality of personnel performance if accompanied by efforts made to make it happen. Efforts made by an organization will have a positive impact on improving the quality of organizational performance so as to support the achievement of the goals that have been set. In order to achieve high performance there are performance criteria, including:

1. Intellectual ability in the form of quality to think logically, practically and analyze in accordance with concepts and abilities and express themselves clearly.

2. Assertiveness, is the ability to analyze possibilities and have a commitment to definite choices in a precise and short manner.

3. Spirit (enthusiasm), in the form of the capacity to work actively and tirelessly tired.

4. Results-oriented, it is an intrinsic desire and has a commitment to achieve results and get the job done.

5. Maturity of proper attitudes and behaviors, is the ability to conduct emotional control and high selfdiscipline.

Discipline is the most important operative function of Human Resource Management, because 
the better the discipline of employees the higher the performance of work that can be achieved. Without good discipline, it is difficult for organizations to achieve optimal results. In general, when people think about discipline, what is imagined is a severe punishment, even though the punishment is only part of the whole disciplinary issue. With good discipline of work is expected to materialize an orderly, effective and successful environment through a clear and appropriate set of regulations.

Generally, this discipline can be seen from indicators such as: teachers come to work on time; dress neatly, politely, pay attention to the ethics of how to dress properly an employee; teachers use tools and equipment according to the provisions, they work vigorously and work in accordance with the rules set by the institution. The above habits will be realized if the employees have good discipline. The cultivation of this discipline certainly needs to be applied by a leader to his subordinates to create a good quality of work.

Applying work discipline at work environment, it will initially be felt heavy by the employees, but if continuously enforced will become a habit, and discipline will not be a heavy burden for employees. This discipline needs to be applied in the work environment, because as mentioned above that discipline is not born just like that, but there needs to be coaching in enforcing this discipline.

A disciplined teacher is defined as a teacher who always comes and goes home on time, does all his work well, adheres to all applicable organizational rules and social norms. Good discipline reflects the great sense of responsibility a person has for the tasks given to him. This encourages work passion, work spirit, and supports the realization of the goals of organizations, employees and communities.

Furthermore, [11] explained that the importance of teacher discipline in carrying out tasks, because teachers must be able to help learners develop patterns of behavior for themselves, help learners improve their standards of behavior, and use the implementation of rules as a tool to enforce discipline. Furthermore, according to Soejono, [12] also stated that teacher discipline can be said to be good, if the employee (teacher) has met several conditions, namely 1) the employees come on time, orderly, orderly, 2) neatly dressed, 3) able to utilize and move the equipment properly, 4) produce a satisfactory job, 5) follow the way the company determines, and 6) have high responsibilities.

The discipline of the teacher's work will be carried out if the supervisor or principal supervises the teachers during their activities. The supervision was carried out to see teachers and other education personnel working in accordance with existing procedures or not. Obedience in carrying out work will also affect that. If a teacher follows school rules, he/she has a high sense of responsibility for the duties given by the headmaster. Good discipline reflects the great sense of responsibility a person has for the task given to him. This can motivate or encourage the spirit of work and the realization of organizational goals or instansi.

To improve teacher performance, each teacher must discipline themselves, by: attending on time every weekday, filling out a list of attendance every weekday, returning home on time every weekday, completing tasks on time, teaching according to the learning syllabus, informing picket teachers when unable to attend, prioritizing the implementation of tasks over other activities and carrying out tasks according to the rules. If teachers cannot discipline themselves then it is the school that applies discipline to teachers in a way: making clear work rules, enforcing positive discipline by warning, giving leave, evaluating up to dismissal.

According to [4] presented the assessment factor of his teacher's work discipline: absentee or attendance, adherence to obligations and regulations, working in accordance with it. Based on the discipline assessment factors stated above, this study uses the work discipline assessment factor presented by [5]. It is chosen because it has been in accordance with working conditions in the field when researching.

\section{METHODS}

This study uses quantitative information with correlational research types because this study aims to look at the influence between one variable and another. [2] stated that correlation research is part of ex-postfacto research, where researchers do not manipulate the state of existing variables and directly look for the existence and extent of variable relationships reflected in the correlation coefficient.

The research was conducted in elementary school in Lempuing Jaya subdistrict, Ogan Komering Ilir Regency. The research period began for four months. The population in this study was all elementary teachers of 265 people in Lempuing Jaya Subdistrict, OKI Regency. Sampling proportionate stratified random sampling. The withdrawal of samples in this way was done because the population had members who were not homogeny and proposional, then in sam[el] numbered 73 people. The data collection techniques used in this study are by using questionnaires/ questionnaires, documentation, and interviews.

This research consists of three variables, 
namely two free variables and one bound variable. The free variables in this study are principal leadership (X1) and teacher discipline (X2), while the variables tied to this research are teacher performance (Y). To avoid misunderstanding in interpreting research variables, it is necessary to formulate the operational definition of each of the research variables.

1. The headmaster's leadership is one of the factors that can help the school to be able to realize its vision, mission, goals and objectives through programs that are carried out in a planned and targeted manner.

2. Discipline of work is an attitude of awareness and willingness of a person to obey all the rules of the company or organization and applicable social norms.

3. Teacher performance as a professional educator with the main task of educating teaching, guiding, directing, training, assessing and evaluating learners in the learning process and achieving school goals.

\section{RESULT AND DISCUSSION}

The Influence of Leadership on Teacher Performance in Lempuing Jaya Subdistrict, Ogan Komering Ilir Regency. The hypothetical test result obtained a probability value (0.000) less than the value of $\alpha(0.05)$, in addition, for the value thitung $(4,526)$ greater tTabel $(1,996)$ so that it can be concluded that Ha is accepted. This means that there is an influence of the headmaster's leadership on the performance of teachers in Lempuing Jaya Subdistrict, Ogan Komering Ilir Regency. The influence of headmaster leadership on teacher performance was $22.4 \%$ of the remaining $77.6 \%$ influenced by other factors that were not variable in his research.

The results of this study showed that the headmaster's leadership had a significant influence on teacher performance. The coefficient of determinants gives an understanding that the relationship between the headmaster's leadership and performance is significant or positive. This means that the better the headmaster's leadership, the higher the performance. The results of this study are in line with the research of [4] stated that there is a positive and significant influence of the headmaster's leadership, work motivation and work discipline on the performance of teachers in MTsN Batuda Gorontalo Regency.

This was also confirmed [12] stated that the headmaster's leadership plays a role in improving the spirit of teacher work in carrying out their duties so that they can create harmonious and pleasant working conditions. Thus, teachers will be more passionate in fostering students both academic and non-academic.
This means that the headmaster's leadership plays a role in improving the teacher's spirit of work in carrying out their duties so that they can create harmonious and pleasant working conditions. Thus, teachers will be more passionate in fostering students both academic and non-academic. Thus, the headmaster's leadership has an influence on the teacher's performance so that the teacher's performance cannot be separated from the influence of the headmaster's leadership. Because the better the headmaster's leadership, the more improved the teacher's performance in carrying out his duties as a teacher.

The Influence of Teacher Discipline on Teacher Performance in Lempuing Jaya Subdistrict, Ogan Komering Ilir Regency

The hypothetical test result obtained a probability value $(0.006)$ less than the value of $\alpha$ (0.05), in addition, for the value thitung $(2,660)$ greater tTabel $(1,996)$ so that it can be concluded that $\mathrm{Ha}$ is accepted. That is, there is an influence of teacher discipline on the performance of public elementary school teachers in Lempuing Jaya Subdistrict, Ogan Komering Ilir Regency. The influence of teacher discipline on teacher performance of $9.1 \%$ of the remaining $90.9 \%$ was influenced by other factors that were not variables in this study.

The results of the above research showed that teacher discipline has a significant influence on teacher performance in implementing teachers. The value of determinant coefficients provides an understanding that the relationship between teacher's work discipline and performance is significant or positive. This means that the higher the level of discipline the teacher's work will be the higher the performance. The results of this study are in line with the research of SyafrinNgiode (2016) which stated that there is a positive and significant influence of work discipline on the performance of teachers in MTsNBatuda Gorontalo Regency.

Furthermore, according to Soejono, [13] also stated that teacher discipline can be said to be good, if the employee (teacher) has met several conditions, namely 1) the employees come on time, orderly, orderly, 2) neatly dressed, 3) able to utilize and move the equipment properly, 4) produce a satisfactory job, 5) follow the way the company determines, and 6) have high responsibilities.

The discipline of the teacher's work will be carried out if the supervisor or principal supervises the teachers during their activities. The supervision was carried out to see teachers and other education personnel working in accordance with existing procedures or not. Obedience in carrying out work will also affect that. If a teacher follows school rules, 
he/she has a high sense of responsibility for the duties given by the headmaster. Good discipline reflects the great sense of responsibility a person has for the task given to him. This can motivate or encourage the spirit of work and the realization of organizational goals or instansi.

The Influence of Leadership and Discipline of Teacher Work Together on Teacher Performance in Lempuing Jaya Subdistrict, Ogan Komering Ilir Regency

The hypothetical test result obtained a probability value $(0.000)$ less than the value of $\alpha$ (0.05), in addition, for the value of Fhitung of 12.004 greater than $\mathrm{F}(0.05)(2: 70)$ of 3.98 so that $\mathrm{Ha}$ is received. That is, there is an influence of the headmaster's leadership and the discipline of teacher work together on the performance of public elementary school teachers in Lempuing Jaya Subdistrict, Ogan Komering Ilir Regency. the influence of headmaster leadership and teacher discipline together on the performance of public elementary school teachers in Lempuing Jaya Subdistrict of Ogan Komering Ilir regency amounted to $25.5 \%$ of the remaining $74.5 \%$ influenced by other factors that were not intended by variables in this study.

The results of this study are in line with the research of [13] conclusions from the results of the study is that there is a positive and significant influence of the headmaster's leadership, work motivation and work discipline on teacher performance in MTsN Batudaa Gorontalo Regency. In addition, the results of research conducted by [14] showed that the leadership of the principal had a significant influence on teacher performance. Thus, the headmaster's leadership plays a very important role in the performance of teachers in order to carry out their duties properly so that educational objectives will be achieved to the maximum.

The results of this study showed that the headmaster's leadership and the disipilin of teacher work influenced the teacher's performance together. This means that the better the headmaster's leadership, the better the teacher's performance in carrying out their duties as educators [15] [16]. In addition, good teacher discipline will improve teacher performance so as to accelerate the achievement of educational goals, while low discipline will decrease teacher performance so that it becomes a barrier and slows down the achievement of organizational goals.

Aside from the headmaster's leadership there are other important factors that affect the improvement of teacher performance, namely teacher discipline. Because good teacher work discipline is very necessary in achieving the expected goals so that the discipline of work affects the performance of teachers in carrying out their duties, because discipline is very important because the discipline of the work is able to be a driving force of willingness and desire to work according to the limits set so that it is clear that the discipline of work should be owned by a teacher in order to support the success of the learning process. Good teacher discipline will improve teacher performance so as to accelerate the achievement of educational goals.

\section{CONCLUSION}

Based on the results of research and discussions it can be concluded that: 1) There is an influence of the leadership of the principal on the performance of elementary school teachers in Lempuing Jaya Subdistrict, Ogan Komering Ilir Regency; 2) There is an influence of teacher discipline on the performance of state elementary school teachers in Lempuing Jaya Subdistrict, Ogan Komering Ilir Regency; 3) There is an influence of leadership and discipline of teacher work together on the performance of elementary school teachers in Lempuing Jaya Subdistrict, Ogan Komering Ilir Regency.

\section{REFERENCES}

[1] Trihastuti, M., Latief, S., \& Kholid, M. R. (2021). The Influence of Teachers' Leadership and Motivation on Social Science Learning Outcomes MA Yahisha Cihampelas Bandung. Bulletin of Science Education, 1(2), 136-144.

[2] Danim, S. (2004). Motivational Leadership \& Effectiveness Group, Jakarta: Rineka Cipta.

[3] Davis, K., \& John W. Newstrom. (1995). Behavior in Organization, (Agus Darma Translation), Jakarta: Erlangga.

[4] A Tabrani R. (2000), Efforts to Improve Teacher Performance Culture, Cianjur: CV Dinamika Karya.

[5] E. Mulyasa. (2009). Became a Professional Principal, Bandung: PT Remaja Rosdakarya.

[6] E. Mulyasa. (2007). Becoming a Professional Teacher. Bandung: PT Remaja Rosdakarya.

[7] Fathoni Abdurrahmat, (2006), Organization and Human Resources Management, Jakarta : PT Rineka Cipta.

[8] Fitria, H. (2020). Effect of Principal Managerial Ability and Work Climate on Teacher Performance: Tambusai Education Journal 4 (3), 3419-3428

[9] Fitria H, Martha A (2020), Principal Leadership Management in Improving Honorary Teacher Performance: Journal of Innovation in Teaching and Instructional Media 1 (1), 85-89 
[10] Kesumawati, N. \& Aridanu, I. (2017). Educational Research Parametric Statistics. Palembang: Noer Fikri.Riduwan. 2013. Belajar Mudah Penelitian untuk GuruKaryawan dan Penelitian Pemula. Bandung: Alfabeta.

[11] Rivai, V. (2004), Organizational Leadership and Behavior, Jakarta: PT Raja Grafindo Persada.

[12] Sedarmayanti. (2009). Human Resources and Work Productivity, Bandung: CV Mandar Maju.

[13] Siagian, S. P. (2002), Tips to Increase Work Productivity, Jakarta: Rineka Jaya.
[14] Siswanto, B. (2005), Manpower Management. Bandung: Sinar Baru.Hafidulloh,

[15] Budiyanto., \& Suhermin. (2017). Effect of Transformational Leadership, Incentive Giving, Professional Development of Work Discipline and Teacher Performance SMK Ma'arif Surabaya Indonesia. The International Journal Of Business \& Management (ISSN 2321-8916).

[16] Agus, S., \& Nurul, M. (2020). Constructive Games to Enhance Multiple Intelligence (Visual-Spatial and Interpersonal) Ability. Journal of Islamic Guidance and Counseling, Vol. Number 02, No. 01 , 